\title{
EFFECT OF HUMIC ACID AND SEAWEED EXTRACTS ON GROWTH AND YIELD OF POTATO PLANT (Solanum tubersum L) DESIREE CV.
}

\author{
Taha Z. Sarhan
}

Hort. Dept., College of Agric., Duhok Univ., Iraq

\begin{abstract}
This study was conducted in College of Agriculture Farms/University of Duhok. At the spring season 2009 on potato plants CV. Desiree. RCBD Design with two factors was applied to study the effect of Humic acid and two seaweed extracts Alga 600 and sea force 2 on potato plants. Humic acid and seaweed extracts treatments caused a significant increase in all vegetative growth and yield characteristics of potato $\mathrm{CV}$ desiree. The interaction between treatments also caused a significant effect and the plants which got a humic acid and sprayed with mixture of Alga 600 and sea force 2 gave the highest values of vegetative characters as compared with lowest values of control plants. Also the results appeared a positive significant effect of humic acid and seaweed extracts and their interactions on all yield quantitative characters.
\end{abstract}

\section{INTRODUCTION}

Potato Solanum tuberosum L.is one of the Solanaceae family plants, considered as one of most important vegetable crops in many regions of the world. Which planted commercially in Iraq since 1960 (Matlob et al 1989). It is considered as a rich crop of nutrient substances and is consumed very large quantities as manufactured, each $100 \mathrm{~g}$ of potato peeled tubers contain $79.80 \mathrm{~g}$. water, 76 calories, $2.10 \mathrm{gm}$ protein, $0.1 \mathrm{gm}$ lipids, $17.1 \mathrm{gm}$ carbohydrates, 0.5 gm fibers and $0.9 \mathrm{gm}$ ash as well as it contains a little quantity of nutrient elements and some vitamins, it contains $0.1 \mathrm{mg}$ thiamin, $0.4 \mathrm{mg}$ Riboflavin, 1.5 $\mathrm{mg}$ Niyasin and $20.0 \mathrm{mg}$ Ascorbic acid (Hassan 2003). Some substances affected on plant growth and its physiological activities, Including humic acid which promote plant growth and induce soil microorganisms like bacteria and fungi and provide carbon as a source for the organisms humic acid as well acting as chelating good martial, and reassen the lack of mineral nutrient and losing them by leaching and also make many nutrient available in soil such as phosphate, calcium and trace elements and finally Humic acid possesses high capability in controlling soil $\mathrm{pH}$ against changes which might occurs from the use of chemical fertilizer (Leonard, 2008). Chen and Avaid (1990) found that humic acid and humus substances had influence on increasing plant physiological activities which reflect on plant growth and its chemical structure, while David et al (1994) in an experiment on tomato transplants growing in nutrient solution contained different concentrations of Humic acid, reported an enhanced and induced effect on transplants growth and increasing its mineral structure, and this was agreed with the results of Adani et al (1998) on tomato plants, which found that humic acid increasing plant growth and its mineral content. Concerning with seaweed extracts, Thomas (1996) applied seaweed (Sea Buckthorn) as soil amendment and he investigated its effects on growth responses of some herbaceous plants (Rosemary plant), he found that 
herbaceous

plants

Received 15/2/2010 Accepted date 21/6/2010 
grown on treated soil had a high response as compared to that grown on untreated soil since the former plant, exhibited more improved nutritional content of macro and micro elements. Kowalski et al (1999) described the positive affection of seaweed extracts on plant growth and yield by using kalpak extracts on potato plant since they affected significantly on shoot growth and leaf content of nutrient minerals and increased quantitative and quality yield traits significantly. Also Jensen (2004) reported that seaweed extracts contain various micro elements $(\mathrm{Cu}, \mathrm{Zn}, \mathrm{Mo}, \mathrm{B}, \mathrm{Co})$ in addition to macro elements and contain Auxins, Gibberellins' and Cytokinins, when spray on plants lead to increase root growth ability, nutrient elements absorption, and stem thickness and growth significantly. Eris et al (2008) showed that seaweed extract Ascophyllum nodosum when sprayed on pepper plants lead to increase growth, yield and concentration of some nutrient elements significantly. Zhang et al (2003), in study to test the combine effect of Humic acid and seaweed extracts on growth and physiology of some herbaceous plants creeping Bentgrass, found positive growth and nutrient content of plant significantly. Also Zhang and Ervin (2004) found that the influence of Cytokinin of seaweed extracts and humic acid tended to improve the resistance of herbaceous plant to drought condition and to increase Cytokinin content and its physiological role in plant. The aim of this investigation was to test the influence of humic acid and two seaweed extracts Alga 600 and sea force 2 on potato plants.

\section{MATERIALS AND METHODS}

The experiment was conducted at the vegetable research farm, college of Agriculture, University of Duhok during spring season 2009. The land was plowed and the soil softened, then divided into ridges $0.75 \mathrm{~cm}$ with $3 \mathrm{~m}$ tall. then irrigated and there after potato tubers were sown at distance of $30 \mathrm{~cm}$. tubers of Desiree cultivars planted at $1^{\text {st }}$ march 2009. Factorial experiment with Randomized Complete Block Design (R.C.B.D). were conducted with two factor, the first humic acid $(\mathrm{H})$ at two levels $\left(\mathrm{H}_{0}\right)$ zero, and $\left(\mathrm{H}_{1}\right)$ at concentration of $3 \mathrm{ml} / \mathrm{l}$ which added with irrigated water, the second factor was spraying by seaweed extract $(\mathrm{E})$ at four levels were $\mathrm{E}_{0}$ (control), $\mathrm{E}_{1}$ sprayed with $0.33 \mathrm{~g} / \mathrm{l}$ of seaweed extract (Alga 600 ), $\mathrm{E}_{2}$ spraying with $3 \mathrm{ml} / \mathrm{l}$ of seaweed extract (sea force 2 ), and $\mathrm{E}_{3}$ sprayed with mixture of $0.33 \mathrm{~g} . \mathrm{l}^{-1}+3 \mathrm{ml} . \mathrm{l}^{-1}$ of the two extracts (Alga 600 and seaforce2). So the experiment consist of (8) treatments $(2 * 4=8)$. Each treatment was replicated three times and each replicated was represented by two ridges humic acid was added and seaweed extracts spray after 1 month from sowing. Uniform cultivation practices were followed according to commercial farmers. Data were analyzed by using SAS program (Anonymous 2001). The recorded data were as following: Vegetative characteristics that include Plant height $(\mathrm{cm})$, number of aerial stems, total chlorophyll, fresh weight of vegetative part (gm), dry weight of vegetative part (gm), and yield characteristics which include tubers number/plant, tuber weight (gm), tuber yield gm/plant, total yield ton/hectare, tuber dry matter.

the composition of HumiMax, (Humic acid and Fulvic acid Liquid $(12+6))$ applied as labeled on the container Humic Acid $\geq 120 \mathrm{~g} / \mathrm{l}$, FulvicAcid $\geq 60 \mathrm{~g} / 1, \mathrm{k} 20 \geq 40 \mathrm{~g} / \mathrm{l}$. Alga 600 (Soluble Seaweed Extract Powder) 
composition as labeled on the container : $\mathrm{N} \geq 1 \% \mathrm{~K}_{2} \mathrm{O} \geq 18.5 \%$, alginic acid $\geq$ $10 \%, \mathrm{Mg} \geq 0.42 \% \mathrm{~S} \geq 2.2 \%$, natural PGR, Vitamin, amino acid, betaine and mannitol. While the composition of the Sea force 2 which Extract of seaweed mixture with trace elements are: $\mathrm{MgO} 3.2 \%, \mathrm{Mn} \mathrm{1.8 \% ,} \mathrm{Zn} \mathrm{2.4 \% ,} \mathrm{S} \mathrm{4.88 \% ,} \mathrm{So}_{3}$ $12.2 \%$.

\section{RESULTS AND DISCUSSION}

1-Vegetative characteristics: Tables (1 and 2) shows that humic acid caused significant differences in all shoot characteristics as compared to the control. As well the spraying plants with seaweed extracts caused positive significant differences as compared to the control. Spraying with a mixture of the extracts of Alga 600 and sea force 2 gave the highest values of shoot growth characteristics. The interaction between humic acid and the spraying with seaweed extracts was significance in its effect. Since potato plants received 3 gm 1-1 humic acid and sprayed with a mixture of 0.33 gm. 1-1 Alga $600+2.5 \mathrm{ml} .1-1$ and sea force2, were characterized by the highest values of plant height $120.5 \mathrm{~cm}$, number of aerial stems per plant 5.28, shoots fresh weight per plant $555.77 \mathrm{gm}$, shoots dry weight per plant $64.43 \mathrm{gm}$, and total chlorophyll content $46.63 \%$ as compared with the least values of the above parameters recorded with control treatment $115.03 \mathrm{~cm}, 4.47$ aerial stem/plant, 457.40gm, 54.42gm, 36.9\% respectively. The increases in shoots characteristics might be due to the influence of humic acid which provides nutrient minerals that involve in plants bioactivities and finally leads to growth induction (Abdel Mawgaud et al., 2007).

Table (1): Effect of humic acid and seaweed extracts on vegetative characters of potato.

\begin{tabular}{|c|c|c|c|c|c|c|}
\hline \multirow{2}{*}{ Treatments } & \multicolumn{2}{|c|}{ Humic acid } & \multicolumn{4}{c|}{ Seaweed Extracts } \\
\cline { 2 - 7 } Characters & $\mathrm{H}_{0}$ & $\mathrm{H}_{1}$ & $\mathrm{E}_{0}$ & $\mathrm{E}_{1}$ & $\mathrm{E}_{2}$ & $\mathrm{E}_{3}$ \\
\hline $\begin{array}{c}\text { Plant height } \\
\text { (cm.) }\end{array}$ & $\begin{array}{c}117.70 \\
\mathrm{a}\end{array}$ & $\begin{array}{c}118.94 \\
\mathrm{a}\end{array}$ & $\begin{array}{c}116.37 \\
\mathrm{~b}\end{array}$ & $\begin{array}{c}118.09 \\
\mathrm{ab}\end{array}$ & $\begin{array}{c}118.88 \\
\mathrm{ab}\end{array}$ & $\begin{array}{c}119.93 \\
\mathrm{a}\end{array}$ \\
\hline $\begin{array}{c}\text { Aerial stem } \\
\text { No. }\end{array}$ & $\begin{array}{c}4.72 \\
\mathrm{~b}\end{array}$ & $\begin{array}{c}4.82 \\
\mathrm{a}\end{array}$ & $\begin{array}{c}4.42 \\
\mathrm{~d}\end{array}$ & $\begin{array}{c}4.65 \\
\mathrm{c}\end{array}$ & $\begin{array}{c}4.92 \\
\mathrm{~b}\end{array}$ & $\begin{array}{c}5.11 \\
\mathrm{a}\end{array}$ \\
\hline $\begin{array}{c}\text { Fresh Weight } \\
\text { (g) }\end{array}$ & $\begin{array}{c}477.075 \\
\mathrm{~b}\end{array}$ & $\begin{array}{c}493.967 \\
\mathrm{a}\end{array}$ & $\begin{array}{c}455.983 \\
\mathrm{~d}\end{array}$ & $\begin{array}{c}469.900 \\
\mathrm{c}\end{array}$ & $\begin{array}{c}486.317 \\
\mathrm{~b}\end{array}$ & $\begin{array}{c}529.88 \\
\mathrm{a}\end{array}$ \\
\hline $\begin{array}{c}\text { Dry Weight } \\
\text { (g) }\end{array}$ & $\begin{array}{c}56.74 \\
\mathrm{~b}\end{array}$ & $\begin{array}{c}58.34 \\
\mathrm{a}\end{array}$ & $\begin{array}{c}38.63 \\
\mathrm{c}\end{array}$ & $\begin{array}{c}41.22 \\
\mathrm{~b}\end{array}$ & $\begin{array}{c}42.95 \\
\mathrm{~b}\end{array}$ & $\begin{array}{c}45.85 \\
\mathrm{a}\end{array}$ \\
\hline $\begin{array}{c}\text { \%Total } \\
\text { chlorophyll }\end{array}$ & $40.66 \mathrm{~b}$ & $43.67 \mathrm{a}$ & $38.63 \mathrm{~d}$ & $41.22 \mathrm{c}$ & $42.95 \mathrm{~b}$ & $45.85 \mathrm{a}$ \\
\hline
\end{tabular}

Means within a column, row and their interaction following with the same latter are not significantly different according to Duncan multiple range test at the probability of 0.05 levels.

Furthermore, humic acid increases the porosity of soil and improve growth of root system which leads to increase the shoot system (Garcia et al, 2008). Mataroiev (2002) describe the role of humats in improving soil physical and chemical characteristics by reaction with soil minerals then improving watery, aerial soil characteristics and nutrient mineral adsorption. Humic acid degrade soil, improve its 
physical, chemical, biological and nutritional characteristics by degrading clay particles and increasing holding water capacity. The increase in shoots characteristics might also be due to the auxins content in the seaweed extracts which have an effective role in cell division and enlargement; this leads to increase the shoot growth, leaves area and plant dry weight (Gollan and Wright, 2006).

Table (2): Effect of interaction of humic acid and seaweed extracts on vegetative characters of potato.

\begin{tabular}{|c|c|c|c|c|c|c|c|c|}
\hline \multirow{2}{*}{ Treatments } & \multicolumn{9}{|c|}{ Humic acid } \\
\cline { 2 - 9 } Characters & \multicolumn{9}{|c|}{$\mathrm{H}_{0}$} & \multicolumn{5}{c|}{$\mathrm{H}_{1}$} \\
\cline { 2 - 10 } & $\mathrm{E}_{0}$ & $\mathrm{E}_{1}$ & $\mathrm{E}_{2}$ & $\mathrm{E}_{3}$ & $\mathrm{E}_{0}$ & $\mathrm{E}_{1}$ & $\mathrm{E}_{2}$ & $\mathrm{E}_{3}$ \\
\hline Plant height & 115.03 & 117.77 & 118.63 & 119.37 & 117.70 & 118.41 & 119.13 & 120.50 \\
(cm.) & $\mathrm{b}$ & $\mathrm{ab}$ & $\mathrm{ab}$ & $\mathrm{a}$ & $\mathrm{ab}$ & $\mathrm{ab}$ & $\mathrm{a}$ & $\mathrm{a}$ \\
\hline Aerial stem & 4.47 & 4.60 & 4.86 & 4.95 & 4.36 & 4.69 & 4.97 & 5.28 \\
No. & $\mathrm{ef}$ & $\mathrm{de}$ & $\mathrm{bc}$ & $\mathrm{b}$ & $\mathrm{f}$ & $\mathrm{cd}$ & $\mathrm{b}$ & $\mathrm{a}$ \\
\hline Fresh Weight & 457.40 & 466.27 & 480.63 & 504.00 & 454.57 & 473.53 & 492.00 & 555.77 \\
(g) & $\mathrm{e}$ & $\mathrm{de}$ & $\mathrm{cd}$ & $\mathrm{b}$ & $\mathrm{e}$ & $\mathrm{d}$ & $\mathrm{bc}$ & $\mathrm{a}$ \\
\hline Dry Weight & 54.42 & 56.32 & 57.02 & 59.21 & 53.85 & 57.34 & 57.73 & 64.43 \\
(g) & $\mathrm{d}$ & $\mathrm{c}$ & $\mathrm{c}$ & $\mathrm{b}$ & $\mathrm{d}$ & $\mathrm{cd}$ & $\mathrm{bc}$ & $\mathrm{a}$ \\
\hline \% Total & 36.90 & 39.33 & 41.33 & 45.07 & 40.37 & 43.10 & 44.57 & 46.63 \\
chlorophyll & $\mathrm{e}$ & $\mathrm{d}$ & $\mathrm{cd}$ & $\mathrm{ab}$ & $\mathrm{d}$ & $\mathrm{bc}$ & $\mathrm{ab}$ & $\mathrm{a}$ \\
\hline
\end{tabular}

Means within a column, row and their interaction following with the same latter are not significantly different according to Duncan multiple range test at the probability of 0.05 levels.

Seaweed extracts contain cytokinins as well in which induce the physiological activities (for instance activating some enzymes that involved in photosynthesis) and increase the total chlorophyll in the plant, this will positively Reflect on the activity of photosynthesis and the synthesized materials which will positively reflect on shoots characteristics (Thomas, 1996). This increase in shoots characteristics might also due to the macronutrients content in seaweed extracts. Macronutrients have a great role in plant nutrition like nitrogen, potassium and phosphorous which are very essential for the growth and development of the plant (Attememe, 2009).

2-Yield characteristics: Tables (3 and 4) show that humic acid caused significant effect on all yield characteristics as compared to untreated plants. The tables declared as well that potato plants sprayed with seaweed extracts gave significantly higher yield characteristics as compared to the control plants. The highest values of these traits were recorded in plants sprayed with the extract of seaweed Alga 600 and Sea force2. Concerning the interaction, it was, significantly effective on the qualitative traits. Potato plants received $3 \mathrm{ml}^{-1}{ }^{-1}$ humic acid and sprayed with a mixture of $0.33 \mathrm{gml}^{-1}+3 \mathrm{ml} / \mathrm{L}$ of the Alga 600 and Sea force2 gave the highest values of number of tubers per plant 9.42, the mean weight of tubers $82.49 \mathrm{~g}$, plant yield $0.780 \mathrm{~kg} /$ plant, and total yield per hectare 34.52 ton, tuber dry weight $14.67 \%$ as compared to the control plant which gave the lowest values to same parameters $7.25,73.10 \mathrm{~g}, 0.540 \mathrm{~kg}, 23.88$ ton and 
$13.37 \%$ respectively. The increase in yield characteristics might be due to significant effect of humic acid and seaweed extracts on shoot system further than increase in tuber number/plant and tuber weight which reflect positively on increase of plant yield and total yield. Humic acid characterized by improving plant growth directly or indirectly it act as biostimulant induced hormonal activity of plant releasing different auxin types which in regulating plant growth and environmental responses. Jensen (2004) found that humic acid improve plant growth by improving soil texture and act to increase water, plants roots ability to enter soil and penetrate, Humic acid is very important as transmissive media for nutrition's from soil to plant and increase soil water holding ability and stimulate soil microorganisms activity.

Table (3): Effect of humic acid and seaweed extracts on yield characters of potato.

\begin{tabular}{|c|c|c|c|c|c|c|}
\hline Treatments & & acid & & Seau & Extrac & \\
\hline & $\mathrm{H}_{0}$ & $\mathrm{H}_{1}$ & $\mathrm{E}_{0}$ & $\mathrm{E}_{1}$ & $\mathrm{E}_{2}$ & $\mathrm{E}_{3}$ \\
\hline Tuber No/plant & $\begin{array}{c}7.75 \\
b\end{array}$ & $\begin{array}{c}8.90 \\
\mathrm{a}\end{array}$ & $\begin{array}{c}7.72 \\
b\end{array}$ & $\begin{array}{c}8.08 \\
b\end{array}$ & $\begin{array}{c}8.58 \\
a b\end{array}$ & $\begin{array}{c}8.92 \\
\mathrm{a}\end{array}$ \\
\hline $\begin{array}{l}\text { Tuber weight. } \\
\text { (g) }\end{array}$ & $\begin{array}{c}77.19 \\
a\end{array}$ & $\begin{array}{c}78.31 \\
\mathrm{a}\end{array}$ & $\begin{array}{c}74.06 \\
\text { c }\end{array}$ & $\begin{array}{c}75.72 \\
\text { bc }\end{array}$ & $\begin{array}{c}79.39 \\
\text { ab }\end{array}$ & $\begin{array}{c}81.83 \\
\mathrm{a}\end{array}$ \\
\hline $\begin{array}{c}\text { Yield/plant. } \\
(\mathrm{kg})\end{array}$ & $\begin{array}{c}0.60 \\
\mathrm{~b}\end{array}$ & $\begin{array}{c}0.69 \\
\mathrm{a}\end{array}$ & $\begin{array}{c}0.57 \\
\mathrm{~d}\end{array}$ & $\begin{array}{c}0.61 \\
\mathrm{c}\end{array}$ & $\begin{array}{c}0.67 \\
\mathrm{~b}\end{array}$ & $\begin{array}{c}0.73 \\
\mathrm{a} \\
\end{array}$ \\
\hline $\begin{array}{c}\text { Total yield } \\
\text { (Ton/ hectare) }\end{array}$ & $\begin{array}{c}26.84 \\
b\end{array}$ & $\begin{array}{c}29.44 \\
\mathrm{a}\end{array}$ & $\begin{array}{c}25.16 \\
d\end{array}$ & $\begin{array}{c}27.32 \\
\mathrm{c}\end{array}$ & $\begin{array}{l}29.76 \\
b\end{array}$ & $\begin{array}{c}32.44 \\
\mathrm{a}\end{array}$ \\
\hline $\begin{array}{c}\% \\
\text { tuber dry Weight }\end{array}$ & $\begin{array}{c}13.66 \\
b\end{array}$ & $\begin{array}{c}14.17 \\
\mathrm{a}\end{array}$ & $\begin{array}{l}13.67 \\
b\end{array}$ & $\begin{array}{c}13.72 \\
b\end{array}$ & $\begin{array}{c}13.90 \\
\mathrm{~b}\end{array}$ & $\begin{array}{c}14.37 \\
\mathrm{a}\end{array}$ \\
\hline
\end{tabular}

Means within a column, row and their interaction following with the same latter are not significantly different according to Duncan multiple range test at the probability of 0.05 levels.

Table (4): Effect of interaction of humic acid and seaweed extracts on yield characters of potato.

\begin{tabular}{|c|c|c|c|c|c|c|c|c|}
\hline \multirow[t]{3}{*}{ Treatments } & \multicolumn{8}{|c|}{ Humic acid } \\
\hline & \multicolumn{4}{|c|}{$\mathrm{H}_{0}$} & \multicolumn{4}{|c|}{$\mathrm{H}_{1}$} \\
\hline & \multicolumn{4}{|c|}{ Seaweed Extract } & \multicolumn{4}{|c|}{ Seaweed Extract } \\
\hline Characters & $\mathrm{E}_{0}$ & $\mathrm{E}_{1}$ & $\mathrm{E}_{2}$ & $\mathrm{E}_{3}$ & $\mathrm{E}_{0}$ & $\mathrm{E}_{1}$ & $\mathrm{E}_{2}$ & $\mathrm{E}_{3}$ \\
\hline Tuber No/plant & 7.25 & 7.42 & 7.92 & 8.42 & 8.18 & 8.75 & 9.25 & 9.42 \\
\hline & $\mathrm{f}$ & ef & de & $\mathrm{cd}$ & $\mathrm{cd}$ & $\mathrm{bc}$ & $a b$ & $\mathrm{a}$ \\
\hline Tuber weight & 73.10 & 75.49 & 78.98 & 81.18 & 75.01 & 75.95 & 79.80 & 82.49 \\
\hline$(\mathrm{g})$ & $\mathrm{c}$ & $\mathrm{bc}$ & $a-c$ & $\mathrm{ab}$ & $\mathrm{bc}$ & $\mathrm{bc}$ & $\mathrm{ab}$ & $\mathrm{a}$ \\
\hline Yield/plant & 0.54 & 0.57 & 0.63 & 0.68 & 0.59 & 0.66 & 0.71 & 0.78 \\
\hline$(\mathrm{kg})$ & $\mathrm{f}$ & ef & $\mathrm{d}$ & $\mathrm{bc}$ & $\mathrm{de}$ & $\mathrm{c}$ & $\mathrm{b}$ & $\mathrm{a}$ \\
\hline Total yield & 23.88 & 25.2 & 27.8 & 30.4 & 26.4 & 29.44 & 29.56 & 34.52 \\
\hline
\end{tabular}




\begin{tabular}{|c|c|c|c|c|c|c|c|c|}
\hline (Ton/ hectare) & $\mathrm{f}$ & ef & $\mathrm{d}$ & $\mathrm{bc}$ & $\mathrm{de}$ & $\mathrm{c}$ & $\mathrm{b}$ & $\mathrm{a}$ \\
\hline \% Tuber dry & 13.37 & 13.43 & 13.77 & 14.07 & 13.97 & 14.00 & 14.03 & 14.67 \\
\hline Weight & $\mathrm{c}$ & $\mathrm{bc}$ & $\mathrm{bc}$ & $\mathrm{b}$ & $\mathrm{bc}$ & $\mathrm{b}$ & $\mathrm{b}$ & $\mathrm{a}$ \\
\hline
\end{tabular}

Means within a column, row and their interaction following with the same latter are not zignificantly different according to Duncan multiple range test at the probability of 0.05 level

Humic acid and seaweed extracts caused significant increases in shoot growth traits, furthermore, the increase of the number of tubers and their weight which positively reflected on increasing the plant yield and the total yield. The reasons behind these results might also be due to that the added humic acid is characterized by its high content of nutrient elements as well as providing nutrient base that increase the activity of the microorganisms (Tisdale et al1997). Further than, improving the physical and chemical characteristics of the soil, all these reflected positively on the plant yield. Seaweed extracts has to equilibrium in growth as a result of the present auxins which will increase vitamins and hormones producing in the treated plants. As well as it contains $\mathrm{GA}_{3}, \mathrm{GA}_{7}$ and vitamin, Further than containing trace elements which are the most important sea plant components which is present in achelate state combined with iron in calkalius soils. It is available for plants. The chelate compounds are as carbohydrates combined with iron so it will be available to improve photosynthesis efficiency. (O' Dell, 2003). These results are in agreement with what has been found by Kowalski et al. (1999), who illustrated the positive effect of seaweed extracts (kalpak extract) on the growth of the plant and increasing the total yield of potato plants, the treatment significantly affected on the shoot growth characteristics and leaves content of nutrient elements and increased the qualitative and quantitative characteristics of the yield significantly.

تاثير حامض الهيومك وبعض مستخلصات الاعثاب البحرية في نمو وانتاج محصول البطاطا

Solanum tubersum 1. Desiree CV.

$$
\text { قسم البستنة - كلية الزير سرحة - جامعة دهوك }
$$

\section{الخلاصة}

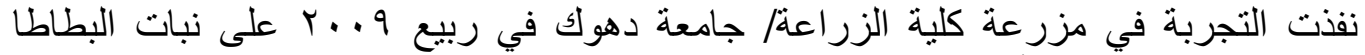

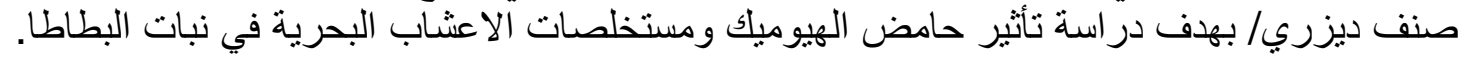

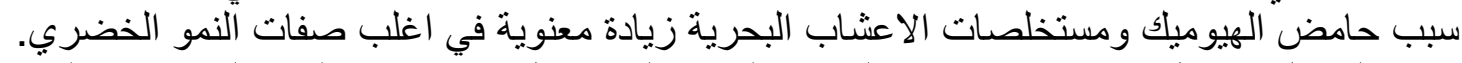

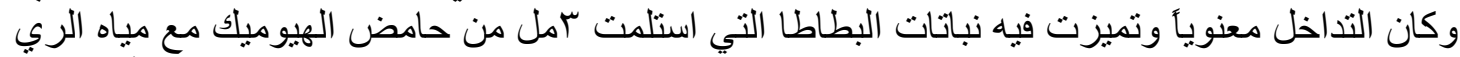

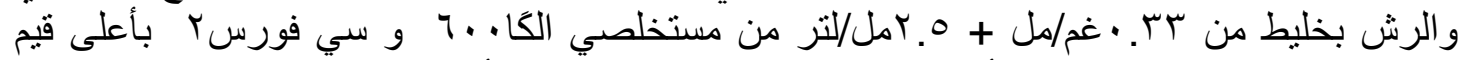

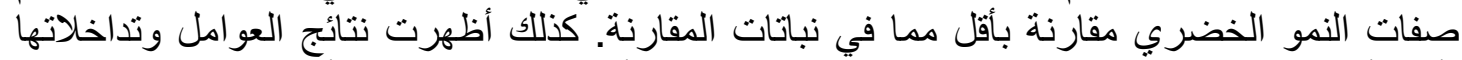
تأثثر أيجابي معنوي لُحامض الهيوميك و مستخلصات الأعثاب البحرية في أغلب صفات التهات الحاصل

\section{REFERENCE}

Abdel-Mawgoud, A. M. R., N. H. M, El- Greudy, Y. I. Helmy and S. M. Singer (2007). Responses of tomato plants to different rates of humic based fertilizer and NPK fertilization. J. Applied Sci. Research. 3(2):169-174. 
Adani. F., P. Genevini, P. Zaccheo and G. Zocchi (1998). The effect of commercial humic on tomato plant growth and mineral nutrition .J. of Plant Nutrition. 21:562-575.

Anonymous (2001). SAS User's Guide. Release 6-12 SAS Institute Inc. Cary, N.C., USA.

Attememe. J. Y. A. (2009). The effect of humic acid and sea weed extracts on the growth, chemical characteristics and oil characteristics of Rosmarinus officinalis L. the $6^{\text {th }}$ scientific conference, Biology Dept., College of Education, University of Tikrit. Plants Sci. P. 1-17.

Chen, Y. and T. Avaid (1990). Effect of humic substances on plant growth. American Society of Agronomy and Soil Science (eds) :PP. 161-186.

David, P. P., P. V. Nelson and D. G. Sanders (1994). A humic acid improves growth of tomato seedling in solution culture. J. of Plant Nutrition 7:173184.

Eris, A., H. O. Sirritepe and N. Sirritepe (2008). The effect of seaweed (Ascophyllum nodosum) Extract on yield and quality criteria in pipers. Acta Horti. (ISHS) 412:733-737.

Garcia, M. C. V., F. S. Estrella, M. J. Lopez and J. Moreno (2008). Influence of compost amendment on soil biological properties and plants. Dynamic Soil, Dynamic Plant. 1. 1-9.

Gollan, J. R. and J. T. Wright (2006). Limited grazing pressure by native herbivores on the invasive seaweed caulerpa. Taxi folia in a temperate. Australia Estuary Marine and Freshwater Research. 57(7):685-694.

Hassan, A. A. (2003). Potato. Dar-Al-Arabiya Publications. Cairo. Egypt.

Jensen, E. (2004) Seaweed; Fact or Fanc. From the Organic Broadcaster, Published by Moses the Midwest Organic and Sustainable Education. From the Broad Caster. 12(3): 164-170.

Kowalski, B., A. K. Jager and J. Vanstaden (1999). The effect of a seaweed concentrate on the invitro growth and acclimatization of potato plants. Potato Research. 42(1): 131-139.

Leonard, A. G. (2008). Humic acid: 100\% Natural, Many Uses. Goldend Harvest organic. LLCTM.

Mataroiev, I. A. (2002). Effect of humate on diseases plant resistance. Ch. Agri. J. 1:15-16. Russian.

Matlob, A. N., E. Sultan, and K. S. Abdul (1989). Vegetable Production Part one and two. Dar Al-Kutub Publication. Mosul Univ., Iraq. (In Arabic).

O' Dell, C. (2003). Natural plant hormones are bio stimulants helping plants develop high plant antioxidant Activity for multiple benefits. Virginia Vegetable, Small Fruit and Specialty Crops. 2(6):1-3.

Thomas, S. C. L. (1996). Nutrient weeds as soil amendments for organic cally growth herbs. Jour of Herbs, Spices and Medicinal Plant. 4(1): 3-8.

Thomas, S.C. L. (2002). Production Development of sea buckthorn. L., T. S. Product Development of sea buckthorn P. 393-398. In J. Janik and A. Whipke (Eds). Trends in New Crops and New Uses ASHS, Alexandria,. VA. 
Tisdale, S. L., W. L. Nelson, J. D. Beaton and J. L. Harllin, (1997). Soil Fertility and Fertilizers. Prentice. Hall of India, New Delhi.

Zhang, X., E. H. Ervinad R. E. Schmidt (2003). Physiological effects of liquid application of a seaweed extract and humic acid on creeping bent grass. J. of Amer. Hort. Sci. 128:492-496.

Zhang, X. and E. H. Ervine (2004). Cytokinin-containing seaweed and humic acid extracts associated with Creeping bent grass leaf cytokinins and drought resistance. Crops. 44:1737-1745. 